\title{
Managing Environmental Risk in Presence of Climate Change: The Role of Adaptation in the Nile Basin of Ethiopia
}

\author{
Salvatore Di Falco and Marcella Veronesi
}

\begin{abstract}
This study investigates the impact of climate change adaptation on farm households' downside risk exposure in the Nile Basin of Ethiopia. The analysis relies on a moment-based specification of the stochastic production function. We use an empirical strategy that accounts for the heterogeneity in the decision on whether to adapt or not, and for unobservable characteristics of farmers and their farm. We find that past adaptation to climate change (i) reduces current downside risk exposure, and subsequently the risk of crop failure; (ii) would have been more beneficial to the non-adapters if they adapted, in terms of reduction in downside risk exposure; and (iii) is a successful risk management strategy that makes the adapters more resilient to climatic conditions.
\end{abstract}

JEL Classification D80 • Q18・Q54

This book chapter appeared previously on environmental and resource economics 2014 vol 57(4):553-577.

Previous versions of this paper have been presented at the 2012 Nordic Economic Development conference, the 2012 annual meeting of the Environment for Development Initiative, the 2011 EAERE (European Association of Environmental and Resource Economics) meeting, the 2011 AES (Agricultural Economics Society) Meeting, at the 2011 EAAE (European Association of Agricultural Economics), and at the 2010 Ascona Workshop on "Environmental Decisions: Risks and Uncertainties." We would like to thank session participants for suggestions. We also would like to thank the three anonymous reviewers for their comments and suggestions. All remaining errors and omissions are our own responsibility. Funding from SIDA through the Environment for Development Initiative is gratefully acknowledged.

\footnotetext{
S. Di Falco $(\square)$

Department of Economics, University of Geneva, Geneva, Switzerland

e-mail: salvatore.difalco@unige.ch
}

M. Veronesi

Department of Economics, University of Verona, Verona, Italy 


\section{Introduction}

One consequence of climate change in sub Saharan Africa is that farmers will be more exposed to environmental risk. More erratic and scarce rainfall and higher temperature imply that farmers will face greater uncertainty. Ethiopia is a prime example in that rainfall variability and associated drought have been major causes of food shortage and famine. During the last 40 years, Ethiopia has experienced many severe droughts leading to production levels that fell short of basic subsistence levels for many farm households (Relief Society of Tigray, REST and NORAGRIC at the Agricultural University of Norway 1995, p. 137). Harvest failure due to weather events is the most important cause of risk-related hardship of Ethiopian rural households, with adverse effects on farm household consumption and welfare (Dercon 2004, 2005). Climate change is projected to further exacerbate these issues (Parry et al. 2005; Lobell et al. 2008; Schlenker and Lobell 2010; World Bank 2010). Thus, the implementation of adaptation strategies can be very important (Mendelsohn and Dinar 2003; Deressa et al. 2009; Di Falco and Veronesi 2013). For instance, farmers may face drier soil, and therefore they implement investments in soil conservation so that soil moisture may be retained. They can plant trees to procure shading on the soil or utilize irrigation and water harvesting technologies (Kurukulasuriya et al. 2011). They can also simply switch to different crops or activities that are more suited to drier or wetter environmental conditions (Seo and Mendelsohn 2008a). ${ }^{1}$

This paper uses survey data from the Nile basin of Ethiopia (IFPRI 2010) to investigate whether having adapted to climate change, defined as having implemented a set of strategies such as changing crop varieties, adopting water harvesting or soil and water conservation in response to long-term changes temperature and rainfall, affects current environmental risk exposure. In particular, we pose the following questions:

1. Are farm households that in the past implemented climate change adaptation strategies getting benefits in terms of a reduction in current risk exposure?

2. Are there significant differences in risk exposure between farm households that did and those that did not adapt to climate change?

3. Is climate change adaptation a successful risk management strategy that makes the adapters more resilient to current environmental risk?

The Nile basin of Ethiopia provides a relevant area to address these issues for a number of reasons. This is a very large area that covers about $34 \%$ of the total geographical area and almost $40 \%$ of the population of the entire country (Deressa et al. 2009). Farming is characterized by small-holder subsistence farmers. Farm size is on average quite small (less than one hectare). Production is traditional with plough

\footnotetext{
${ }^{1}$ It can be argued that if the production conditions become too challenging, farmers may see less of a scope for action (i.e., prospects are too gloomy) and be forced out of agriculture and migrate. However, this possibility (along with other non-crop related strategies) have not been observed in the sample used in our study.
} 
and animals' draught power. Labor is the major input in the production process during land preparation, planting, and post-harvest processing. The use of other inputs is extremely limited (Deressa et al. 2009). The region is prone to extreme weather events such as droughts and floods. These have often resulted in crop failure, water shortage, and food insecurity (Di Falco et al. 2011). Drought is characterized by abnormal soil water deficiency. This is due to climatic variability, such as precipitation shortage or increased evapotranspiration (Gadisso 2007). Moreover, a number of papers have looked at either the impact of climate change on productivity or farm revenues (e.g., Deressa and Hassan 2009; Di Falco et al. 2011; Di Falco and Veronesi 2013) as well as the determinants of adaptation (Deressa et al. 2009, 2011; Di Falco et al. 2011). ${ }^{2}$ However, the study of the risk implications of adaptation to climate change has been overlooked. This paper aims to fill this gap.

For our purpose, it is important to identify a suitable metric to capture the extent of environmental risk. In a rainfed agricultural production setting, the focus on crop failure seems natural. Avoiding crop failure is indeed the major preoccupation of farmers in Ethiopia. This is captured by the downside risk exposure measured by the skewness of yields. Our analysis relies on a moment-based specification of the stochastic production function (Antle 1983; Antle and Goodger 1984; Chavas 2004). This method has been widely used in the context of risk management in agriculture (Just and Pope 1979; Kim and Chavas 2003; Koundouri et al. 2006). It could be argued that the variance of yields is also a possible measure of risk exposure. However, it should be noted that the variance does not distinguish between unexpected good and bad events. We therefore focus on the skewness in risk analysis, that is we approximate downside risk exposure by the lack of symmetry of crop yield distribution. If the skewness of yield increases and becomes positive, then it means that downside risk exposure decreases, that is the probability of crop failure decreases (Di Falco and Chavas 2009). This approach can thus capture a fuller extent of risk exposure.

We investigate the effects of climate change adaptation on risk exposure in an endogenous switching regression framework. ${ }^{3}$ The survey collected information on both farm households that did and did not adapt plus on a very large set of control variables. We take into account that the differences in risk exposure between those farm households that did and those that did not adapt to climate change could be due to unobserved heterogeneity. Not distinguishing between the casual effect of climate change adaptation and the effect of unobserved heterogeneity could lead to misleading policy implications. We account for the endogeneity of the adaptation decision by estimating a simultaneous equations model with endogenous switching by full information maximum likelihood estimation. In addition, we build a

\footnotetext{
${ }^{2}$ There are other very relevant studies addressing similar issues in different countries or at a different scale. The interested reader is referred to Mendelsohn et al. (1994), Gbetibouo and Hassan (2005), Seo and Mendelsohn (2008b), Hassan and Nhemachena (2008), Kurukulasuriya and Mendelsohn (2008), and Seo et al. (2009).

${ }^{3}$ This framework allows for testing the exogeneity hypothesis, in this case correcting for selection bias. It is especially useful when risks vary across categories, but have absolute thresholds.
} 
counterfactual analysis, and compare the expected downside risk exposure under the actual and counterfactual cases of whether the farm household did or did not adapt to climate change. Treatment and heterogeneity effects are calculated to understand the differences in downside risk exposure between farm households that adapted and those that did not adapt.

Key findings of our analysis are that:

1. past adaptation to climate change decreases current downside risk exposure, and thereby the risk of crop failure;

2. there are significant and non-negligible differences in risk exposure between adapters and non-adapters;

3. farm households that did not adapt would benefit the most in terms of reduction in downside risk exposure from adaptation; and

4. the implementation of adaptation strategies is a successful risk management strategy that makes the adapters more resilient to climatic conditions.

The paper proceeds as follows. Sections 2 and 3 describe the study sites and survey instruments. Section 4 outlines the model and the estimation procedure used. Section 5 presents the results, and section 6 concludes by offering some final remarks and directions for future research.

\section{Background}

Ethiopia's GDP is closely associated with the performance of its rainfed agriculture (Deressa and Hassan 2009). For instance, about 40 percent of national GDP, 90 percent of exports, and 85 percent of employment stem from the agricultural sector (Ministry of Finance and Economic Development, MoFED 2007). The rainfed production environment is characterized by land degradation and very erratic and variable climate. Rainfall variability and associated droughts have been major causes of food shortage and famine in Ethiopia (World Bank 2010). A recent mapping on vulnerability and poverty in Africa listed Ethiopia as one of the most vulnerable countries to climate change with the least capacity to respond (Orindi et al. 2006; Stige et al. 2006).

The success of the agricultural sector is crucially determined by the productivity of small holder farm households. They account for about 95 percent of the national agricultural output, of which about 75 percent is consumed at the household level (World Bank 2006). With low diversified economy and reliance on rain-fed agriculture, Ethiopia's development prospects have been thus associated with climate (Deressa et al. 2009). For instance, the World Bank (2006) reported that catastrophic hydrological events such as droughts and floods have reduced its economic growth by more than a third. The frequency of droughts has increased over the past few decades, especially in the lowlands (Lautze et al. 2003). A 2007 study, undertaken by the national meteorological service (NMS), highlights that the annual minimum temperature has been increasing by about 0.37 degrees Celsius every 10 years over 
the past 55 years. Rainfall has been more erratic with some areas becoming drier while others becoming relatively wetter. These findings show that climatic variations are already happened in this part of the world. The prospect of further climate change can exacerbate this already difficult situation. Climate change is projected to further reduce agricultural productivity (Rosenzweig and Parry 1994; Parry et al. 2005; Cline 2007). Most climate models converge in forecasting scenarios of increased temperatures for most of Ethiopia (Dinar et al. 2008).

\section{Survey Design and Data Description}

The survey was carried out in the Nile River Basin in Ethiopia in 2005. ${ }^{4}$ The household sampling frame was developed to ensure representation for the Nile River Basin at the woreda (an administrative division equivalent to a district) level regarding level of rainfall patterns in terms of both annual total and variation. The data used for the sample frame are from the Atlas of the Ethiopian Rural Economy (IFPRI 2010). The survey considered traditional typology of agro-ecological zones in the country (namely, Dega, Woina Dega, Kolla, and Berha), percent of cultivated land, degree of irrigation activity, average annual rainfall, rainfall variability, and vulnerability (number of food aid dependent population). The sampling frame selected the woredas in such a way that each stratum in the sample matched to the proportions for each stratum in the entire Nile basin. The procedure resulted in the inclusion of twenty woredas. Random sampling was then used in selecting fifty households from each woreda. The final dataset contains comprehensive observations from almost 1000 farms. Information on agricultural practices and production, costs, investments, and revenues as well as tenure security, past shocks, and access to credit were collected. ${ }^{5}$ One of the survey instruments was in particular designed to capture farmers' perceptions and understanding on climate change, and their approaches for adaptation. Questions were included to investigate whether farmers have noticed changes in mean temperature and rainfall over the last two decades, and reasons for observed changes. Overall, increased temperature and declining rainfall are the predominant perceptions in our study sites. These perceptions do match with the existing evidence reported in the previous section.

Furthermore, some questions investigated whether farm households made some adjustments in their farming practices in response to long-term changes in mean temperature and rainfall by adopting some particular strategies. Changing crop varieties and adoption of soil and water conservation strategies were major forms of adaptation strategies followed by the farm households in our study sites. These adaptation strategies are mainly yield-related and account for more than 95 per cent of the adaptation strategies followed by the farm households who actually undertook an adaptation strategy. The remaining adaptation strategies accounting for less

\footnotetext{
${ }^{4}$ To our knowledge there has not been a follow up survey yet.

${ }^{5}$ For complete information on the survey, please refer to IFPRI (2010).
} 
than five percent were water harvesting, irrigation, non-yield related strategies such as migration, and shift in farming practice from crop production to livestock herding or other sectors. We use this information from the survey to create the variable adaptation. This is equal to 1 if a farm household adopted any of the above strategies, and to 0 otherwise.

As mentioned, detailed production data were collected at different production stages (i.e., land preparation, planting, weeding, harvesting, and post-harvest processing). Most of the sample population is composed of rainfed farms (less than 9 per cent of them have access to irrigation). Ethiopian rural households face high weather and climatic variability. Significant spatial variations exist in agroecological conditions, including topography, soil type, temperature, and soil fertility (Hagos et al. 1999). ${ }^{6}$ The farming system in the survey sites is very traditional with plough and animals' draught power. Labor is the major input in the production process during land preparation, planting, and post-harvest processing. Labor inputs were disaggregated as adult male labor, adult female labor, and children labor. The three forms of labor were aggregated as one labor input using adult equivalents. ${ }^{7}$

Monthly rainfall and temperature data were collected from all the meteorological stations in the country for the period 1970-2000. Then, the Thin Plate Spline method of spatial interpolation was used to impute the household specific rainfall and temperature values using latitude, longitude, and elevation information of each household. The Thin Plate Spline is a physically based two-dimensional interpolation scheme for arbitrarily spaced tabulated data. The Spline surface represents a thin metal sheet that is constrained not to move at the grid points, which ensures that the generated rainfall and temperature data at the weather stations are exactly the same as data at the weather station sites that were used for the interpolation. In our case, the rainfall and temperature data at the weather stations are reproduced by the interpolation for those stations, which ensures the credibility of the method (see Wahba 1990). This method is one of the most commonly used to create spatial climate data sets (e.g., Di Falco et al. 2011; Deressa and Hassan 2009). Its strengths are that it is readily available, relatively easy to apply, and accounts for spatially varying elevation relationships. However, it only simulates elevation relationships and has difficulty handling very sharp spatial gradients, which can be typical of coastal areas. Given that our area of the study is characterized by significant terrain features, and no climatically important coastlines, the choice of the Thin Spline method is reasonable (for more details on the properties of this method in comparison to the other methods see Daly 2006).

\footnotetext{
${ }^{6}$ Note that the cross-section and plot level nature of the data does not allow an analysis of the dynamic aspects of farm-level management decisions. Panel data would be required to explore such issues. To our knowledge, there is no climate change survey where the same household has been interviewed in different point in time.

${ }^{7} \mathrm{We}$ employed the OECD/EU conversion factor in the literature in developing countries, where adult female and child labor are converted into the adult male labor equivalent with the conversion factors 0.8 and 0.3 , respectively.
} 
However, it should be noted that the impact of variations in temperature and rainfall may vary across seasons, and should be taken into account. ${ }^{8}$ We therefore investigate the differential impact of the two main rainy seasons in Ethiopia: the long rainy season (Meher) and the short rainy season (Belg). We do not distinguish between differences in temperatures between seasons because we did not find large differences in average temperature between months in the period 1970-2000. This may be related to the location of Ethiopia near the Equator.

The final sample includes twenty woredas, 941 farm households (i.e., on average about forty-seven farm households per woreda), and 2801 plots (i.e., on average about three plots per farm household). The scale of the analysis is at the plot-level. ${ }^{9}$ The basic descriptive statistics are presented in Table 1, and the definition of the variables in Table A1 of the appendix (Table A2).

\section{Model of Climate Change Adaptation and Risk Exposure}

In this section we specify an econometric model of climate change adaptation and risk exposure. Particular functional forms are chosen to remain within the spirit of previous work in this area (Di Falco et al. 2011). The simplest approach to examine the impact of climate change adaptation on farm households' downside risk exposure would be to include in the risk equation a dummy variable equal to one if the farm household adapted to climate change, and then, to apply ordinary least squares. This approach, however, might yield biased estimates because it assumes that adaptation to climate change is exogenously determined while, in fact, it may be endogenous to other factors. Namely, the decision on whether to adapt or not to climate change is voluntary and may be based on individual self-selection. Farmers that adapted may have systematically different characteristics from the farmers that did not adapt, and they may have decided to adapt based on expected benefits. Unobservable characteristics of farmers and their farm may affect both the adaptation decision and risk exposure, resulting in inconsistent estimates of the effect of adaptation on production risk and risk of crop failure. For example, if only the most skilled or motivated farmers chose to adapt and we fail to control for skills, then we will incur upward bias.

We account for the endogeneity of the adaptation decision by estimating a switching regression model of climate change adaptation and risk exposure with endogenous switching. In particular, we model the climate change adaptation

\footnotetext{
${ }^{8}$ We thank a reviewer for emphasizing this aspect.

${ }^{9}$ Although a total of 48 annual crops were grown in the basin, the first five major annual crops (teff, maize, wheat, barley, and beans) cover 65 per cent of the plots. These are also the crops that constitute the staple foods of the local diet and are relevant in the context of self-subsistence farming. It should be also noted that including the other crops (e.g., perennials) would have implication for the specification of the production technology represented by the production function. We therefore limit the estimation to these primary, annual, crops.
} 
Table 1 Descriptive statistics

\begin{tabular}{|c|c|c|c|c|c|c|}
\hline \multirow[t]{2}{*}{ Variable name } & \multicolumn{2}{|c|}{ Total sample } & \multicolumn{2}{|l|}{ Adapters } & \multicolumn{2}{|c|}{ Non-adapters } \\
\hline & Mean & Std. Dev. & Mean & Std. Dev. & Mean & Std. Dev. \\
\hline \multicolumn{7}{|c|}{ Dependent variables } \\
\hline Adaptation & 0.690 & 0.463 & 1.000 & 0.000 & 0.000 & 0.000 \\
\hline Skewness & 0.593 & 14.877 & 0.845 & 17.903 & 0.034 & 0.320 \\
\hline \multicolumn{7}{|c|}{ Explanatory variables } \\
\hline \multicolumn{7}{|c|}{ Climatic factors } \\
\hline $\begin{array}{l}\text { Average } \\
\text { temperature }\end{array}$ & 18.523 & 2.228 & 17.945 & 1.991 & 19.809 & 2.190 \\
\hline Belg rainfall & 257.064 & 146.275 & 224.635 & 135.490 & 329.284 & 143.617 \\
\hline Meher rainfall & 960.439 & 293.511 & 910.282 & 304.337 & 1072.136 & 231.788 \\
\hline \multicolumn{7}{|l|}{ Crops varieties } \\
\hline Barley & 0.185 & 0.389 & 0.208 & 0.406 & 0.135 & 0.342 \\
\hline Maize & 0.199 & 0.399 & 0.194 & 0.396 & 0.211 & 0.408 \\
\hline Teff & 0.271 & 0.445 & 0.242 & 0.428 & 0.336 & 0.473 \\
\hline Wheat & 0.208 & 0.406 & 0.212 & 0.409 & 0.200 & 0.401 \\
\hline \multicolumn{7}{|c|}{ Soil characteristics } \\
\hline Highly fertile & 0.280 & 0.449 & 0.257 & 0.437 & 0.333 & 0.472 \\
\hline Infertile & 0.158 & 0.365 & 0.172 & 0.378 & 0.127 & 0.333 \\
\hline No erosion & 0.484 & 0.500 & 0.472 & 0.499 & 0.510 & 0.500 \\
\hline Severe erosion & 0.104 & 0.306 & 0.114 & 0.318 & 0.082 & 0.274 \\
\hline \multicolumn{7}{|l|}{ Assets } \\
\hline Machinery & 0.019 & 0.136 & 0.024 & 0.153 & 0.007 & 0.085 \\
\hline Animals & 0.874 & 0.332 & 0.887 & 0.317 & 0.845 & 0.362 \\
\hline \multicolumn{7}{|l|}{ Inputs } \\
\hline Labor & 101.088 & 121.383 & 105.912 & 133.503 & 90.344 & 87.743 \\
\hline Seeds & 115.181 & 148.732 & 125.867 & 163.948 & 91.385 & 103.552 \\
\hline Fertilizers & 60.760 & 176.962 & 62.092 & 177.988 & 57.795 & 174.720 \\
\hline Manure & 198.572 & 832.187 & 254.955 & 952.355 & 73.009 & 438.860 \\
\hline \multicolumn{7}{|c|}{ Farm head and farm household characteristics } \\
\hline Literacy & 0.489 & 0.500 & 0.524 & 0.500 & 0.414 & 0.493 \\
\hline Male & 0.926 & 0.262 & 0.932 & 0.252 & 0.914 & 0.281 \\
\hline Married & 0.928 & 0.259 & 0.931 & 0.254 & 0.922 & 0.269 \\
\hline Age & 45.740 & 12.548 & 46.267 & 11.914 & 44.566 & 13.790 \\
\hline Household size & 6.603 & 2.189 & 6.765 & 2.136 & 6.243 & 2.261 \\
\hline Off-farm job & 0.249 & 0.433 & 0.286 & 0.452 & 0.169 & 0.375 \\
\hline Relatives & 16.494 & 43.682 & 19.561 & 51.321 & 9.473 & 13.287 \\
\hline Access to credit & 0.259 & 0.438 & 0.306 & 0.461 & 0.156 & 0.363 \\
\hline Flood & 0.172 & 0.378 & 0.217 & 0.412 & 0.074 & 0.261 \\
\hline Drought & 0.443 & 0.497 & 0.565 & 0.496 & 0.171 & 0.376 \\
\hline \multicolumn{7}{|c|}{ Information sources } \\
\hline $\begin{array}{l}\text { Government } \\
\text { extension }\end{array}$ & 0.609 & 0.488 & 0.761 & 0.427 & 0.270 & 0.444 \\
\hline
\end{tabular}


Table 1 (continued)

\begin{tabular}{l|l|l|l|l|l|l}
\hline Variable name & \multicolumn{3}{l}{ Total sample } & Adapters & \multicolumn{2}{l}{ Non-adapters } \\
\hline & Mean & Std. Dev. & Mean & Std. Dev. & Mean & Std. Dev. \\
\hline $\begin{array}{l}\text { Farmer-to-farmer } \\
\text { extension }\end{array}$ & 0.516 & 0.500 & 0.659 & 0.474 & 0.197 & 0.398 \\
\hline $\begin{array}{l}\text { Radio } \\
\text { information }\end{array}$ & 0.307 & 0.461 & 0.382 & 0.486 & 0.139 & 0.347 \\
\hline $\begin{array}{l}\text { Neighborhood } \\
\text { information }\end{array}$ & 0.316 & 0.465 & 0.321 & 0.467 & 0.305 & 0.461 \\
\hline $\begin{array}{l}\text { Climate } \\
\text { information }\end{array}$ & 0.422 & 0.494 & 0.563 & 0.496 & 0.111 & 0.314 \\
\hline \begin{tabular}{l} 
Sample size \\
\hline
\end{tabular}
\end{tabular}

The sample size refers to the total number of plots. The final total sample includes 20 woredas, 941 farm households, and 2801 plots

decision and its implications in terms of risk exposure in the setting of a two-stage framework. ${ }^{10}$ In the first stage, we use a selection model where a representative farm household chooses whether to adapt or not to adapt, while in the second stage we estimate conditional risk exposure functions accounting for the endogenous selection. Finally, we produce selection-corrected predictions of counterfactual downside risk exposure.

Stage I - Selection Model of Climate Change Adaptation In the first stage, we use a selection model for climate change adaptation where a representative risk averse farm household $i$ chooses to implement climate change adaptation strategies if the expected utility from adapting $U\left(\pi_{l}\right)$ is greater than the expected utility from not adapting $U\left(\pi_{0}\right)$, i.e., $E\left[U\left(\pi_{1}\right)-U\left(\pi_{0}\right)\right]>0$, where $E$ is the expectation operator based on the subjective distribution of the uncertain variables facing the decision maker, and $U(\bullet)$ is the von Neumann-Morgenstern utility function representing the farm household's preferences under risk. Let $A^{*}$ be the latent variable that captures the expected benefits from the adaptation choice with respect to not adapting. We specify the latent variable as.

$$
A_{i}^{*}=\mathbf{z}_{\mathrm{i}} \alpha+\eta_{i} \text { with } A_{i}=\left\{\begin{array}{ll}
1 & \text { if } A_{i}^{*}>0 \\
0 & \text { otherwise }
\end{array},\right.
$$

that is farm household $i$ will choose to adapt $\left(A_{i}=1\right)$ through the implementation of some strategy or set of strategies in response to long term changes in mean temperature and rainfall if $A^{*}>0$, and 0 otherwise. The vector $\mathbf{z}$ represents variables that affect the likelihood to adapt such as the characteristics of the operating farm (e.g., soil fertility and erosion); farm head and farm household's characteristics (e.g., farmer head's age, gender, education, marital status, off-farm job, and farm household size); the presence of assets (e.g., machinery and animals); past climatic

\footnotetext{
${ }^{10} \mathrm{~A}$ more comprehensive model of climate change adaptation is provided by Mendelsohn (2000).
} 
factors (e.g., rainfall and temperature); the experience of previous extreme events (e.g., droughts and floods); whether farmers received information on climate; government and farmer-to-farmer extensions, which can be used as measures of access to information about adaptation strategies. It is also important to address the role of access to credit. Households that have limited access to credit can have less capital available to be invested in the implementation of more costly adaptation strategies (e.g., soil conservation measures). We approximate experience by age and education.

Stage II-Endogenous Switching Regression Model of Downside RiskExposure How do we measure risk exposure and its interplay with adaptation? In the second stage, we estimate the effect of adaptation on the skewness of the distribution of yields. This provides information of the role of adaptation on downside risk exposure. We rely on a moment-based specification of the stochastic production function (Antle 1983; Antle and Goodger 1984; Chavas 2004). This is a very flexible device that has been largely used in agricultural economics to model the implication of weather risk and risk management (Just and Pope 1979; Kim and Chavas 2003; Koundouri et al. 2006; Di Falco and Chavas 2009). Consider a risk averse farm household that produces output $y$ using inputs $\mathbf{x}$ under risk through a production technology represented by a well-behaved (i.e., continuous and twice differentiable) stochastic production function $y=g(\mathbf{x}, \mathbf{v})$, where $\mathbf{v}$ is a vector of random variables representing risk, that is uncontrollable factors affecting output such as current changes in temperature and rainfall.

We assess the probability distribution of the stochastic production function $\mathrm{g}(\mathbf{x}$, v) by applying a moment-based approach (Antle 1983), that is risk exposure is represented by the moments of the production function $g(\mathbf{x}, \mathbf{v})$. We consider the following econometric specification for $g(\mathbf{x}, \mathbf{v})$ :

$$
g(\mathbf{x}, v)=f_{1}\left(\mathbf{x}, \beta_{1}\right)+u
$$

where $f_{1}\left(\mathbf{x}, \boldsymbol{\beta}_{1}\right) \equiv E[g,(\mathbf{x}, \mathbf{v})]$ is the mean of $g,(\mathbf{x}, \mathbf{v})$, that is the first central moment, and $u=g,(\mathbf{x}, \mathbf{v})-f_{1}\left(\mathbf{x}, \boldsymbol{\beta}_{1}\right)$ is a random variable with mean zero whose distribution is exogenous to farmers' actions. ${ }^{11}$ The higher moments of $g(\mathbf{x}, \mathbf{v})$ are given by

$$
E\left\{\left[g, \mid(\mathbf{x}, v)-f_{1}\left(\mathbf{x}, \mid \beta_{1}\right)\right]^{k},, \mid \mathbf{x}\right\}=f_{k}\left(\mathbf{x}, \beta_{\mathbf{k}}\right)
$$

for $\mathrm{k}=2,3$. This implies that $f_{2}\left(\mathbf{x}, \boldsymbol{\beta}_{2}\right)$ is the second central moment, that is the variance, and $f_{3}\left(\mathbf{x}, \boldsymbol{\beta}_{3}\right)$ is the third central moment, that is the skewness. This approach provides a flexible representation of the impacts of past climatic factors (e.g.,

\footnotetext{
${ }^{11}$ Note that the production function can be estimated by OLS without making any normality assumptions regarding the error distribution. Indeed, if the errors were normally distributed, by construction the distribution would be symmetric, and the third central moment would be zero.
} 
temperature and rainfall averages 1970-2000), ${ }^{12}$ inputs, (e.g., seeds, fertilizers, manure, and labour), assets (e.g., machinery and animals), farm household characteristics, and soil characteristics (e.g., soil fertility and erosion level) on the distribution of output under production uncertainty. As mentioned in the introduction we capture the extent of risk exposure by the third moment of the distribution of yields: the skewness. An increase in skewness implies a reduction in downside risk exposure, which implies, a reduction in the probability of crop failure. Reducing downside risk means decreasing the asymmetry (or skewness) of the risk distribution toward high outcome, holding both means and variance constant ${ }^{13}$ (Menezes et al. 1980; Di Falco and Chavas 2009).

To account for selection biases we adopt an endogenous switching regression model of downside risk exposure where farmers face two regimes (1) to adapt, and (2) not to adapt defined as follows:

$$
\begin{gathered}
\text { Regime 1: } y_{1 i}=\mathbf{x}_{1 \mathrm{i}} \beta_{1}+\varepsilon_{1 i} \text { if } A_{i}=1 \\
\text { Regime 2: } y_{2 i}=\mathbf{x}_{2 \mathrm{i}} \beta_{2}+\varepsilon_{2 i} \text { if } A_{i}=0
\end{gathered}
$$

where $y_{\mathrm{i}}$ is the third central moment $f_{3}\left(\mathbf{x}, \boldsymbol{\beta}_{3}\right)$ of production function (2) in regimes 1 and 2, i.e., the skewness; and $\mathbf{x}_{\mathbf{i}}$ represents a vector of the past climatic factors, inputs, assets, farm head's, farm household's and soil's characteristics included in $\mathbf{z}$. In addition, the error terms in Eqs. (1, 4a, and 4b) are assumed to have a trivariate normal distribution, with zero mean and covariance matrix $\boldsymbol{\Sigma}$, i.e., $\left(\eta, \varepsilon_{1}, \varepsilon_{2}\right)^{\prime} \sim N(\mathbf{0}$, $\boldsymbol{\Sigma})$ with $\Sigma=\left[\begin{array}{ccc}\sigma_{\eta}^{2} & \sigma_{\eta 1} & \sigma_{\eta 2} \\ \sigma_{1 \eta} & \sigma_{1}^{2} & \cdot \\ \sigma_{2 \eta} & \cdot & \sigma_{2}^{2}\end{array}\right]$, where $\sigma_{\eta}^{2}$ is the variance of the error term in the selection Eq. (1), which can be assumed to be equal to 1 since the coefficients are estimable only up to a scale factor (Maddala 1983, p. 223), $\sigma_{1}^{2}$ and $\sigma_{2}^{2}$ are the variances of the error terms in the skewness functions ( $4 \mathrm{a}$ and $4 \mathrm{~b}$ ), and $\sigma_{1 \eta}$ and $\sigma_{2 \eta}$ represent the covariance of $\eta_{i}$ and $\varepsilon_{1 i}$ and $\varepsilon_{2 i}{ }^{14}$ Since $y_{1 \mathrm{i}}$ and $y_{2 \mathrm{i}}$ are not observed simultaneously the covariance between $\varepsilon_{1 i}$ and $\varepsilon_{2 i}$ is not defined (reported as dots in the covariance matrix $\boldsymbol{\Sigma}$, Maddala 1983, p. 224). An important implication of the error structure is that because the error term of the selection Eq. (1) $\eta_{i}$ is correlated

\footnotetext{
${ }^{12}$ It should be noted that the use of averages is conventional in this strand of literature (e.g., Mendelsohn et al. 1994; Deressa and Hassan 2009). Recently, however, a more precise agronomic measure of heat stress has been suggested: degree days. This is a piecewise-linear function of temperature captured by two variable degree days $10-30{ }^{\circ} \mathrm{C}$ (Schlenker and Lobell 2010). The appropriate calculation of these requires a large amount of daily weather observations. Unfortunately, we do not have access to such detailed information.

${ }^{13}$ This does not provide information on the role of adaptation on farmer's welfare under uncertainty.

${ }^{14}$ For notational simplicity, the covariance matrix $\boldsymbol{\Sigma}$ does not reflect the clustering implemented in the empirical analysis.
} 
with the error terms of the skewness functions ( $4 \mathrm{a}$ and $4 \mathrm{~b})\left(\varepsilon_{1 i}\right.$ and $\left.\varepsilon_{2 i}\right)$, the expected values of $\varepsilon_{1 i}$ and $\varepsilon_{2 i}$ conditional on the sample selection are nonzero:

$$
E\left[\varepsilon_{1 i} \mid A_{i}=1\right]=\sigma_{1 \eta} \frac{\phi\left(\mathbf{z}_{\mathbf{i}} \alpha\right)}{\Phi\left(\mathbf{z}_{\mathbf{i}} \alpha\right)}=\sigma_{1 \eta} \lambda_{1 i} \text {, and } E\left[\varepsilon_{2 i} \mid A_{i}=0\right]=-\sigma_{2 \eta} \frac{\phi\left(\mathbf{z}_{\mathbf{i}} \alpha\right)}{\Phi\left(\mathbf{z}_{\mathbf{i}} \alpha\right)}=\sigma_{2 \eta} \lambda_{2 i},
$$

where $\phi($.$) is the standard normal probability density function, \Phi($.$) the standard$ normal cumulative density function, and $\lambda_{1 i}=\frac{\phi\left(\mathbf{z}_{\mathbf{i}} \alpha\right)}{\Phi\left(\mathbf{z}_{\mathbf{i}} \alpha\right)}$, and $\lambda_{2 i}=\frac{\phi\left(\mathbf{z}_{\mathbf{i}} \alpha\right)}{1-\Phi\left(\mathbf{z}_{\mathbf{i}} \alpha\right)}$. If the estimated covariances $\sigma_{1 \eta}$ and $\sigma_{2 \eta}$ are statistically significant, then the decision to adapt and downside risk exposure are correlated, that is we find evidence of endogenous switching and reject the null hypothesis of the absence of sample selectivity bias. This model is defined as a "switching regression model with endogenous switching" (Maddala and Nelson 1975).

For the model to be identified it is important to use as exclusion restrictions, thus as selection instruments, not only those automatically generated by the nonlinearity of the selection model of adaptation (1) but also other variables that directly affect the selection variable but not the outcome variable. Following Di Falco et al. (2011), we use as selection instruments the variables related to the information sources (e.g., government extension, farmer-to-farmer extension, information from the radio or the neighbourhood and, if received information in particular on climate), which enter in $\mathbf{z}$ but not in $\mathbf{x}$. We establish the admissibility of these instruments by performing the simple falsification test by Di Falco et al. (2011): if a variable is a valid selection instrument, it will affect the adaptation decision but it will not affect the risk exposure among farm households that did not adapt. The information sources can be considered as valid selection instruments: they are statistically significant determinants of the decision on whether to adapt or not to climate change $\left(\chi^{2}=108.27\right)$ but not of downside risk exposure among farm households that did not adapt $($ F-stat. $=2.10)$.

Finally, we estimate Stage I and II simultaneously by full information maximum likelihood estimation (FIML) since this is a more efficient method to estimate endogenous switching regression models than a two-step procedure (Lee and Trost 1978). ${ }^{15}$ The logarithmic likelihood function given the previous assumptions regarding the distribution of the error terms is.

$$
\begin{gathered}
\ln L_{i}=\sum_{i=1}^{N} A_{i}\left[\ln \phi\left(\frac{\varepsilon_{1 i}}{\sigma_{1}}\right)-\ln \sigma_{1}+\ln \Phi\left(\theta_{1 i}\right)\right] \\
+\left(1-A_{1}\right)\left[\ln \phi\left(\frac{\varepsilon_{2 i}}{\sigma_{2}}\right)-\ln \sigma_{2}+\ln \left(1-\Phi\left(\theta_{2 i}\right)\right)\right], \text { where }
\end{gathered}
$$

\footnotetext{
${ }^{15}$ The two-step procedure (see Maddala 1983, p. 224 for details) not only it is less efficient than FIML but it also requires some adjustments to derive consistent standard errors (Maddala 1983, p. 225), and it poorly performs in case of high multicollinearity between the covariates of the selection equation (1) and the covariates of the skewness equations (4a) and (4b) (Hartman 1991; Nelson 1984; Nawata 1994).
} 
$\theta_{j i}=\frac{\left(\mathbf{z}_{\mathbf{i}} \alpha+\rho_{j} \varepsilon_{j i} / \sigma_{j}\right)}{\sqrt{1-\rho_{j}^{2}}}, j=1,2$, with $\rho_{j}$ denoting the correlation coefficient between the error term $\eta_{i}$ of the selection Eq. 1 and the error term $\varepsilon_{j i}$ of Eq. $4 \mathrm{a}$ and $4 \mathrm{~b}$, respectively.

In addition, we exploit plot level information to deal with the issue of farmers' unobservable characteristics such as their skills. Plot level information can be used to construct a panel data and control for farm specific effects (Udry 1996). We follow Mundlak (1978) and Wooldridge (2002) to control for unobservable characteristics. We exploit the plot level information, and insert in the adaptation Eq. (1), in the production Eq. (2), and in the risk equations Eq. (4a and $4 \mathrm{~b}$ ) the average of plot-variant variables $\overline{\mathbf{S}}_{\mathbf{i}}$ such as the inputs used (seeds, manure, fertilizer, and labor). This approach relies on the assumption that the unobservable characteristics $v_{\mathbf{i}}$ are a linear function of the averages of the plot-variant explanatory variables $\overline{\mathbf{S}}_{\mathbf{i}}$, that is $v_{i}=\overline{\mathbf{S}}_{\mathbf{i}} \pi+\psi_{i}$ with $\psi_{i} \sim \operatorname{IIN}\left(0, \sigma_{\psi}^{2}\right)$ and $E\left(\psi_{i} / \overline{\mathbf{S}}_{i}\right)=0$, where $\boldsymbol{\pi}$ is the corresponding vector of coefficients, and $\psi_{i}$ is a normal error term uncorrelated with $\overline{\mathbf{S}}_{i}$.

\subsection{Counterfactual Analysis}

The main objective of our study is to investigate the effect of having adapted to climate change on downside risk exposure, that is to estimate the treatment effect (Heckman et al. 2001). In absence of a self-selection problem, it would be appropriate to assign to the adapters a counterfactual skewness had they not adapted equal to the average skewness among non-adapters with the same observable characteristics. However, as already mentioned, unobserved heterogeneity in the propensity to adapt affecting also risk exposure creates a selection bias that cannot be ignored. The endogenous switching regression model just described can be applied to produce selection-corrected predictions of counterfactual downside risk exposure (i.e., skewness). It can be used (a) to compare the expected downside risk exposure of farm households that adapted relative to the non-adapters, (b) to investigate the expected downside risk exposure in the counterfactual hypothetical cases that the adapted farm households (i) did not adapt and (ii) that the non-adapters adapted. The conditional expectations for downside risk exposure in the four cases are defined as follows:

$$
\begin{gathered}
E\left(y_{1 i} \mid A_{i}=1\right)=\mathbf{x}_{1 \mathbf{i}} \beta_{\mathbf{1}}+\sigma_{1 \eta} \lambda_{1 i} \\
E\left(y_{2 i} \mid A_{i}=0\right)=\mathbf{x}_{2 \mathbf{i}} \beta_{\mathbf{2}}+\sigma_{2 \eta} \lambda_{2 i}
\end{gathered}
$$




$$
\begin{aligned}
& E\left(y_{2 i} \mid A_{i}=1\right)=\mathbf{x}_{1 \mathbf{i}} \beta_{2}+\sigma_{2 \eta} \lambda_{1 i} \\
& E\left(y_{1 i} \mid A_{i}=0\right)=\mathbf{x}_{2 \mathbf{i}} \beta_{\mathbf{1}}+\sigma_{1 \eta} \lambda_{2 i}
\end{aligned}
$$

Equation $6 \mathrm{a}$ and $6 \mathrm{~b}$ represent the actual expectations observed in the sample. Equation $6 \mathrm{c}$ and $6 \mathrm{~d}$ represent the counterfactual expected outcomes. In addition, following Heckman et al. (2001), we calculate the effect of the treatment "to adapt" on the treated (TT) as the difference between (6a and $6 \mathrm{c}$ ),

$$
T T=E\left(y_{1 i} \mid A_{i}=1\right)-E\left(y_{2 i} \mid A_{i}=1\right)=\mathbf{x}_{1 \mathbf{i}}\left(\beta_{\mathbf{1}}-\beta_{\mathbf{2}}\right)+\left(\sigma_{1 \eta}-\sigma_{2 \eta}\right) \lambda_{1 i}
$$

which represents the effect of climate change adaptation on downside risk exposure of the farm households that actually adapted to climate change. Similarly, we calculate the effect of the treatment on the untreated (TU) for the farm households that actually did not adapt to climate change as the difference between ( $6 \mathrm{~d}$ and $6 \mathrm{~b})$,

$$
T U=E\left(y_{1 i} \mid A_{i}=0\right)-E\left(y_{2 i} \mid A_{i}=0\right)=\mathbf{x}_{2 \mathbf{i}}\left(\beta_{1}-\beta_{2}\right)+\left(\sigma_{1 \eta}-\sigma_{2 \eta}\right) \lambda_{2 i}
$$

We can use the expected outcomes described in Eq. 6a, 6b, 6c, and $6 \mathrm{~d}$ to calculate also the heterogeneity effects. For example, farm households that did not adapt may have been exposed to lower downside risk than farm households that adapted regardless of the fact that they decided not to adapt but because of unobservable characteristics such as their abilities. We follow Carter and Milon (2005) and define as "the effect of base heterogeneity" for the group of farm households that decided to adapt as the difference between (6a and $6 \mathrm{~d})$,

$$
B H_{1}=E\left(y_{1 i} \mid A_{i}=1\right)-E\left(y_{1 i} \mid A_{i}=0\right)=\left(\mathbf{x}_{1 \mathbf{i}}-\mathbf{x}_{2 \mathbf{i}}\right) \beta_{1 \mathbf{i}}+\sigma_{1 \eta}\left(\lambda_{1 i}-\lambda_{2 i}\right)
$$

Similarly for the group of farm households that decided not to adapt, "the effect of base heterogeneity" is the difference between ( $6 c$ and $6 b$ ),

$$
B H_{2}=E\left(y_{2 i} \mid A_{i}=1\right)-E\left(y_{2 i} \mid A_{i}=0\right)=\left(\mathbf{x}_{1 \mathbf{i}}-\mathbf{x}_{2 \mathbf{i}}\right) \beta_{2 \mathbf{i}}+\sigma_{2 \eta}\left(\lambda_{1 i}-\lambda_{2 i}\right)
$$

Finally, we investigate the "transitional heterogeneity" (TH), that is whether the effect of adapting to climate change is larger or smaller for the adapters or for the non-adapters in the counterfactual case that they did adapt, that is the difference between Eqs. (7 and 8), i.e., (TT) and (TU). 


\section{Results}

Table 2 reports the estimates of the endogenous switching regression model estimated by full information maximum likelihood with clustered standard errors at the woreda level. ${ }^{16}$ The first column presents the estimation of downside risk exposure by ordinary least squares (OLS) with no switching and with a dummy variable equal to 1 if the farm household adapted to climate change, 0 otherwise. The second, third and fourth columns present, respectively, the estimated coefficients of selection Eq. (1) on climate change adaptation, and of downside risk exposure, which is represented by skewness functions ( $4 \mathrm{a}$ and $4 \mathrm{~b}$ ) (i.e., the third central moments of production function (2) in regimes (1) and (2)), for adapters and non-adapters. ${ }^{17}$ Table A3 of the appendix shows the estimation of production function (2) in regimes (1) and (2) from which we derived the third central moments. ${ }^{18}$

The estimation of Eq. (1) suggests that key drivers of farm households' decision to adopt some strategies in response to long-term changes in mean temperature and rainfall are represented by the information sources farm households have access to and the environmental characteristics of the farm. More specifically access to government extension, media, and climate information increase the likelihood to adapt. These findings are very consistent with what has been found elsewhere (e.g., Maddison 2006; Deressa et al. 2009; Hassan and Nhemachena 2008; Gbetibouo et al. 2010; Deressa et al. 2011; Di Falco et al. 2011). Farm households with highly fertile soils are less likely to adapt. This highlights that most adaptation intervention is implemented in medium fertility soils. Rainfall in both rainy seasons displays $U$-shaped behaviour. ${ }^{19}$ In addition, we find that literacy has a positive significant effect on adaptation as well as having experienced a flood in the past. This is also consistent with what has been found by Deressa et al. (2009) and Deressa et al. (2011). It may be argued that pooling different crops can induce some bias. There

\footnotetext{
${ }^{16} \mathrm{We}$ recognise that it is possible that the error terms of the switching regression model are correlated among the nearby geographical areas. As rightly pointed out by one of the reviewers, this may arise for several reasons. First, interpolation methods were applied to create spatial climate data sets. This procedure may introduce correlation in the errors. Unobserved soil characteristics are also spatially correlated. Therefore, standard errors should be adjusted for the spatial dependence in the residuals. However, we do not have the information on the distance between plots to adjust the standard errors for spatial dependence and we account for the correlation among plots within the same woreda by clustering the standard errors. Future research should account also for spatial dependence.

${ }^{17}$ We use the "movestay" command of STATA to estimate the endogenous switching regression model by FIML (Lokshin and Sajaia 2004). We rescaled and divided the skewness by 10 milliards to address convergence issues in the FIML estimation. Dividing a number by a constant does not affect the results.

${ }^{18}$ We refer the reader to Di Falco et al. (2011) for a discussion of the factors affecting the production functions of the adapters and non-adapters.

${ }^{19} \mathrm{Di}$ Falco et al. (2011) use current weather as a proxy for climate (while we use climatic variables such as past rainfall and mean temperature), and they do not find an effect of weather on adaptation.
} 
may be some underlying differences in their risk functions, for instance. To control for this possible source of heterogeneity, we included a set of dummy variables to capture the specificity of the different crops. ${ }^{20}$

The question now is whether farm households that implemented climate change adaptation strategies experienced a reduction in downside risk exposure (e.g., a decrease in the probability of crop failure). As described in the previous section, we assess the probability distribution of the stochastic production function by applying a moment-based approach. A simple approach to answer the aforementioned question consists in estimating an OLS model of downside risk exposure that includes a dummy variable equal to 1 if the farm household adapted, 0 otherwise (Table 2, column (1)). An increase in skewness implies a reduction in downside risk exposure. This approach would lead us to conclude that the adaption significantly reduces farm households' downside risk exposure (the coefficient of the dummy variable adaptation is positive), although the effect is weak (significant at the 10 percent statistical level). This approach, however, assumes that adaptation to climate change is exogenously determined, while, in fact, it is a potentially endogenous variable. As such, the estimation via OLS would yield biased and inconsistent estimates. In addition, OLS estimates do not explicitly account for potential structural differences between the skewness functions of the adapters and non-adapters. The estimates presented in the last two columns of Table 2 account for the endogenous switching in the skewness function. Both the estimated coefficients of the correlation terms $\rho_{j}$ are not significantly different from zero (Table 2, bottom row). This implies that the hypothesis of absence of sample selectivity bias may not be rejected.

However, the differences in the coefficients of the skewness functions between the farm households that adapted and those that did not adapt illustrate the presence of heterogeneity in the sample (Table 2, columns (3) and (4)). The skewness function of the adapters is significantly different from the skewness function of the nonadapters (Chow test $\mathrm{p}$-value $=0.000$ ). Among farm households that in the past adapted to climate change, assets such as animals are significantly associated with an increase in the skewness, and so in a decrease in downside risk exposure. Inputs such as seeds display an inverted $U$-shape relationship. The total marginal impact (estimated at the sample mean) is positive. This implies that seeds have a positive effect in reducing downside risk exposure for the group of the adapters. While it is difficult to understand the reasons behind such results, one may speculate that the adapters may have better access to markets for inputs and this allows them to better manage risk of crop failure. Infertile soils are instead associated with an increase in downside risk exposure. However, these factors do not significantly affect the downside risk exposure of farm households that did not adapt. ${ }^{21}$ We find instead that climatic factors play a very important role in explaining risk exposure of the group of non-adapters. These non-adapters are, indeed, significantly affected by the rainfall

\footnotetext{
${ }^{20} \mathrm{We}$ also have estimated models without the crop dummies. Results are robust, and available upon request.

${ }^{21}$ The exception is seeds which displays some weak statistical significance of the positive portion of $U$-shape behaviour. The marginal impact is, however, negligible.
} 
Table 2 Parameters estimates of climate change adaptation and downside risk exposure (skewness)

\begin{tabular}{l|l|l|l|l}
\hline & $(1)$ & $(2)$ & $(3)$ & $(4)$ \\
\hline Model & OLS & \multicolumn{2}{|l}{ Endogenous switching regression ${ }^{\mathrm{a}}$} \\
\hline & & & $\begin{array}{l}\text { Regime 1 } \\
\text { (adaptation = 1) }\end{array}$ & $\begin{array}{l}\text { Regime 2 } \\
\text { (adaptation =0) }\end{array}$ \\
\hline Dependent variable & $\begin{array}{l}\text { Skewness } \\
\text { pooled sample }\end{array}$ & $\begin{array}{l}\text { Adaptation } \\
1 / 0\end{array}$ & $\begin{array}{l}\text { Skewness } \\
\text { adapters }\end{array}$ & $\begin{array}{l}\text { Skewness } \\
\text { non-adapters }\end{array}$ \\
\hline Adaptation 1/0 & $4.402 *$ & & & \\
\hline & $(2.539)$ & & & \\
\hline
\end{tabular}

\section{Climatic factors}

\begin{tabular}{|c|c|c|c|c|}
\hline Average temperature & 11.139 & 0.744 & 0.604 & -0.102 \\
\hline & $(8.270)$ & $(0.588)$ & $(1.726)$ & $(0.161)$ \\
\hline \multirow{2}{*}{$\begin{array}{l}\text { squared average } \\
\text { temperature }\end{array}$} & -0.276 & $-0.027 *$ & -0.009 & 0.004 \\
\hline & $(0.228)$ & $(0.015)$ & $(0.050)$ & $(0.005)$ \\
\hline \multirow[t]{2}{*}{ Belg rainfall } & -0.044 & $-0.013 * * *$ & -0.001 & $0.002 * *$ \\
\hline & $(0.070)$ & $(0.003)$ & $(0.005)$ & $(0.001)$ \\
\hline \multirow{2}{*}{$\begin{array}{l}\text { Squared Belg } \\
\text { rainfall/1000 }\end{array}$} & 0.046 & $0.017 * * *$ & 0.003 & $-0.002 *$ \\
\hline & $(0.119)$ & $(0.005)$ & $(0.009)$ & $(0.001)$ \\
\hline \multirow[t]{2}{*}{ Meher rainfall } & 0.081 & $-0.010 * * *$ & 0.013 & $0.001 * *$ \\
\hline & $(0.053)$ & $(0.002)$ & $(0.009)$ & $(0.001)$ \\
\hline \multirow{2}{*}{$\begin{array}{l}\text { squared Meher } \\
\text { rainfall/1000 }\end{array}$} & -0.381 & $0.049 * * *$ & -0.063 & $-0.007 * * *$ \\
\hline & $(0.276)$ & $(0.011)$ & $(0.051)$ & $(0.003)$ \\
\hline \multicolumn{5}{|l|}{ Crop varieties } \\
\hline \multirow[t]{2}{*}{ Barley } & 20.588 & $-0.237 * * *$ & 2.725 & -0.004 \\
\hline & $(13.500)$ & $(0.079)$ & $(1.788)$ & $(0.017)$ \\
\hline \multirow[t]{2}{*}{ Maize } & 5.983 & 0.044 & 0.606 & 0.012 \\
\hline & $(4.596)$ & $(0.109)$ & $(0.516)$ & $(0.036)$ \\
\hline \multirow[t]{2}{*}{ Teff } & -0.161 & -0.062 & -0.143 & -0.001 \\
\hline & $(2.978)$ & $(0.088)$ & $(0.407)$ & $(0.016)$ \\
\hline \multirow[t]{2}{*}{ Wheat } & -0.335 & -0.164 & 0.058 & 0.044 \\
\hline & $(4.067)$ & $(0.083)$ & $(0.617)$ & $(0.031)$ \\
\hline \multicolumn{5}{|l|}{ Soil characteristics } \\
\hline \multirow[t]{2}{*}{ Highly fertile } & -4.913 & $-0.190 * *$ & -0.724 & 0.004 \\
\hline & $(4.583)$ & $(0.076)$ & $(0.716)$ & $(0.016)$ \\
\hline \multirow[t]{2}{*}{ Infertile } & $-5.910 * *$ & -0.076 & $-0.808 * *$ & 0.021 \\
\hline & $(2.308)$ & $(0.104)$ & $(0.352)$ & $(0.016)$ \\
\hline \multirow[t]{2}{*}{ No erosion } & -1.843 & 0.068 & -0.201 & 0.017 \\
\hline & $(6.068)$ & $(0.103)$ & $(0.857)$ & $(0.023)$ \\
\hline \multirow[t]{2}{*}{ Severe erosion } & -3.912 & -0.028 & -0.411 & 0.022 \\
\hline & $(8.794)$ & $(0.093)$ & (1.157) & $(0.046)$ \\
\hline
\end{tabular}


Table 2 (continued)

\begin{tabular}{|c|c|c|c|c|}
\hline & (1) & (2) & (3) & $(4)$ \\
\hline Model & OLS & \multicolumn{3}{|c|}{ Endogenous switching regression ${ }^{\mathrm{a}}$} \\
\hline \multicolumn{5}{|l|}{ Assets } \\
\hline \multirow[t]{2}{*}{ Machinery } & $-9.344^{*}$ & 0.877 & -0.974 & -0.029 \\
\hline & $(4.778)$ & $(0.574)$ & $(0.702)$ & $(0.088)$ \\
\hline \multirow[t]{2}{*}{ Animals } & 3.885 & 0.205 & $0.523 *$ & -0.011 \\
\hline & $(2.389)$ & $(0.202)$ & $(0.282)$ & $(0.028)$ \\
\hline \multicolumn{5}{|l|}{ Inputs } \\
\hline \multirow[t]{2}{*}{ Labor } & -0.047 & & -0.006 & 0.000 \\
\hline & $(0.042)$ & & $(0.005)$ & $(0.000)$ \\
\hline \multirow[t]{2}{*}{ Squared labor/100 } & 0.003 & & $0.0003 *$ & -0.000 \\
\hline & $(0.002)$ & & $(0.0002)$ & $(0.000)$ \\
\hline \multirow[t]{2}{*}{ Seeds } & $0.062 * * *$ & & $0.007 * * *$ & -0.000 \\
\hline & $(0.011)$ & & $(0.001)$ & $(0.000)$ \\
\hline \multirow[t]{2}{*}{ Squared seeds $/ 100$} & $-0.003 * * *$ & & $-0.0003^{* * *}$ & $0.000 *$ \\
\hline & $(0.001)$ & & $(0.000)$ & $(0.000)$ \\
\hline \multirow[t]{2}{*}{ Fertilizers } & -0.021 & & -0.004 & -0.000 \\
\hline & $(0.018)$ & & $(0.003)$ & $(0.000)$ \\
\hline \multirow{2}{*}{$\begin{array}{l}\text { Squared } \\
\text { fertilizers/100 }\end{array}$} & 0.0005 & & 0.0001 & 0.000 \\
\hline & $(0.0005)$ & & $(0.000)$ & $(0.000)$ \\
\hline \multirow[t]{2}{*}{ Manure } & 0.006 & & 0.001 & -0.000 \\
\hline & $(0.004)$ & & $(0.000)$ & $(0.000)$ \\
\hline \multirow[t]{2}{*}{ Squared manure/100 } & $-0.0001 * *$ & & $-0.000^{*}$ & 0.000 \\
\hline & $(0.00003)$ & & $(0.000)$ & $(0.000)$ \\
\hline \multicolumn{5}{|c|}{ Farm head and farm household characteristics } \\
\hline \multirow[t]{2}{*}{ Literacy } & 11.712 & $0.188^{*}$ & 1.540 & $-0.068^{*}$ \\
\hline & $(8.323)$ & $(0.101)$ & $(0.992)$ & $(0.033)$ \\
\hline \multirow[t]{2}{*}{ Male } & 0.752 & 0.118 & 0.028 & 0.066 \\
\hline & $(2.361)$ & $(0.271)$ & $(0.310)$ & $(0.068)$ \\
\hline \multirow[t]{2}{*}{ Married } & 4.741 & -0.273 & 0.657 & -0.090 \\
\hline & $(3.014)$ & $(0.371)$ & $(0.405)$ & $(0.097)$ \\
\hline \multirow[t]{2}{*}{ Age } & 0.538 & 0.006 & 0.082 & $-0.002 *$ \\
\hline & $(0.386)$ & $(0.005)$ & $(0.053)$ & $(0.001)$ \\
\hline \multirow[t]{2}{*}{ Household size } & -1.355 & $0.042 *$ & -0.187 & 0.000 \\
\hline & $(1.039)$ & $(0.023)$ & $(0.126)$ & $(0.005)$ \\
\hline \multirow[t]{2}{*}{ Off-farm job } & 6.078 & 0.099 & 0.811 & -0.010 \\
\hline & $(6.161)$ & $(0.138)$ & $(0.778)$ & $(0.028)$ \\
\hline \multirow[t]{2}{*}{ Relatives } & -0.009 & 0.0003 & -0.001 & $0.001 * *$ \\
\hline & $(0.019)$ & $(0.001)$ & $(0.002)$ & $(0.000)$ \\
\hline \multirow[t]{2}{*}{ Access to credit } & 11.855 & 0.207 & 1.509 & $-0.060 * *$ \\
\hline & (10.175) & $(0.146)$ & $(1.240)$ & $(0.027)$ \\
\hline Flood & -12.952 & 0.196* & -1.611 & -0.052 \\
\hline
\end{tabular}


Table 2 (continued)

\begin{tabular}{|c|c|c|c|c|}
\hline & (1) & (2) & (3) & (4) \\
\hline \multirow[t]{2}{*}{ Model } & OLS & \multicolumn{3}{|c|}{ Endogenous switching regression ${ }^{\mathrm{a}}$} \\
\hline & (9.797) & $(0.112)$ & (1.210) & $(0.044)$ \\
\hline \multirow[t]{2}{*}{ Drought } & 0.172 & -0.033 & -0.113 & 0.054 \\
\hline & $(4.750)$ & $(0.234)$ & $(0.496)$ & $(0.101)$ \\
\hline \multicolumn{5}{|c|}{ Mundlak's fixed effects } \\
\hline \multirow[t]{2}{*}{ Mean fertilizers } & 0.011 & -0.000 & 0.002 & 0.0001 \\
\hline & $(0.012)$ & $(0.001)$ & $(0.001)$ & $(0.0002)$ \\
\hline \multirow[t]{2}{*}{ Mean seeds } & 0.007 & -0.0003 & 0.002 & 0.0001 \\
\hline & $(0.021)$ & $(0.001)$ & $(0.003)$ & $(0.0001)$ \\
\hline \multirow[t]{2}{*}{ Mean manure } & -0.004 & -0.0001 & -0.0003 & 0.0001 \\
\hline & $(0.003)$ & $(0.0002)$ & $(0.0003)$ & $(0.0001)$ \\
\hline \multirow[t]{2}{*}{ Mean labor } & 0.015 & 0.0002 & -0.0002 & -0.0002 \\
\hline & $(0.037)$ & $(0.001)$ & $(0.004)$ & $(0.0003)$ \\
\hline \multicolumn{5}{|l|}{ Information sources } \\
\hline \multirow{2}{*}{$\begin{array}{l}\text { Government } \\
\text { extension }\end{array}$} & & $0.352 * * *$ & & \\
\hline & & $(0.128)$ & & \\
\hline \multirow{2}{*}{$\begin{array}{l}\text { Farmer-to-farmer } \\
\text { extension }\end{array}$} & & 0.098 & & \\
\hline & & $(0.130)$ & & \\
\hline \multirow[t]{2}{*}{ Radio information } & & $0.358 * * *$ & & \\
\hline & & $(0.134)$ & & \\
\hline \multirow{2}{*}{$\begin{array}{l}\text { Neighborhood } \\
\text { information }\end{array}$} & & 0.050 & & \\
\hline & & $(0.120)$ & & \\
\hline \multirow[t]{2}{*}{ Climate information } & & $0.477 * * *$ & & \\
\hline & & $(0.178)$ & & \\
\hline \multirow[t]{2}{*}{ Constant } & $-176.139 *$ & 1.679 & -17.985 & -0.413 \\
\hline & $(88.112)$ & $(5.573)$ & $(13.965)$ & $(1.242)$ \\
\hline \multirow[t]{2}{*}{$\sigma_{i}$} & & & $17.943 * * *$ & $0.313 * * *$ \\
\hline & & & $(6.712)$ & $(0.090)$ \\
\hline \multirow[t]{2}{*}{$\rho_{j}$} & & & -0.035 & -0.731 \\
\hline & & & $(0.029)$ & $(6.335)$ \\
\hline
\end{tabular}

${ }^{a}$ Estimation by full information maximum likelihood at the plot-level. Sample size: 2801 plots. Robust standard errors clustered at the woreda level in parentheses. The dependent variable "skewness" refers to the third central moment $f_{3}\left(\mathbf{x}, \boldsymbol{\gamma}_{3}\right)$ (i.e., downside risk exposure) of production function (2), and it has been rescaled by 10 milliards; $\sigma_{i}$ denotes the square-root of the variance of the error terms $\varepsilon_{j i}$ in the outcome Eq. ( $4 \mathrm{a}$ and $4 \mathrm{~b}$ ), respectively; $\rho_{j}$ denotes the correlation coefficient between the error term $\eta_{i}$ of the selection Eq. (1) and the error term $\varepsilon_{j i}$ of the outcome Eq. (4a and 4 b), respectively.

*Significant at the $10 \%$ level; **Significant at the 5\% level; ***Significant at the $1 \%$ level. 
in both the short and long rainy seasons. The relationship between downside risk exposure and rainfall is inverted $U$-shaped. There is therefore a threshold level after which rainfall does increase the risk of crop failure. This can be due, for instance, to flooding. The adapters, instead, are not (statistically) affected by the climatic factors. This may underscore the fact that the adapters are more successful in managing the risk implications of climate. Besides the climatic variables the number of relatives and access to credit are significantly (at the 5 percent statistical level) correlated with the skewness function of the group of non-adapters. The clear determination of the mechanisms behind these results is not possible in this study as we lack the necessary information. We can, however, offer some interpretations. The estimated coefficient for the variable 'relatives' is positive. Farmers with a larger number of relatives in the village seem to better manage their risk exposure. We can, however, highlight that this may be due to the positive spillovers originated by social networks. Farmers may thus implement agricultural technologies because of social learning or imitation of their relatives (e.g., Bandiera and Rasul 2006; Conley and Udry 2010). The estimated coefficient for access to credit displays, instead, a negative correlation for the group of non-adapters. This is consistent with what has been found in another paper using the same datase ${ }^{22}$ and may indicate that farm households that have accessed credit are those with a lower skewness compared to those that did not access credit.

Table 3 presents the expected downside risk exposure under actual (cells (a) and (b)) and counterfactual conditions (cells (c) and (d)). Cells (a) and (b) represent the expected downside risk exposure observed in the sample of the adapters and nonadapters. The last column presents the treatment effects of adaptation on downside risk exposure. Our results show that adaptation to climate change significantly increases the skewness, that is decreases downside risk exposure, and so the probability of crop failure. In addition, we find that the transitional heterogeneity effect is negative, that is, farm households that did not adapt would have benefited the most in terms of reduction in risk exposure from adaptation. This finding can be explained by analyzing the last row of Table 3, which accounts for the potential heterogeneity in the sample. It shows first, that there is negative selection into choosing to adapt for the adapters, i.e., if the non-adapters had chosen to adapt their risk exposure would have been below that of the adapters; and second, that there is positive selection into not choosing to adapt for the non-adapters, i.e., if the adapters had chosen not to adapt their risk exposure would have been higher than that of the non-adapters. ${ }^{23}$ In short, non-adapters are less exposed to downside risk than the adapters both with adaptation and without adaptation.

\footnotetext{
${ }^{22}$ See Di Falco et al. (2011). The same paper investigated the potential endogeneity of access to credit. Testing procedure rejected this hypothesis at the 1 percent statistical level.

${ }^{23}$ Note that $\mathrm{BH}_{2}$ is negative in Table 3 because it is calculated as the difference between (c) minus (d). However, it is positive if interpreted as (d) minus (c).
} 
Table 3 Average expected downside risk exposure (skewness); treatment and heterogeneity effects

\begin{tabular}{l|l|l|l}
\hline & \multicolumn{2}{l|}{ Decision stage } & \\
\hline Sub-samples & To adapt & Not to adapt & Treatment effects \\
\hline Adapters & $(\mathrm{a}) 0.814$ & $(\mathrm{c})-0.333$ & $\mathrm{TT}=1.146 * * *$ \\
& $(0.050)$ & $(0.004)$ & $(0.048)$ \\
\hline Non-adapters & $(\mathrm{d}) 1.510$ & $(\mathrm{~b}) 0.043$ & $\mathrm{TU}=1.466 * * *$ \\
& $(0.065)$ & $(0.002)$ & $(0.064)$ \\
\hline $\begin{array}{l}\text { Heterogeneity } \\
\text { effects }\end{array}$ & $\mathrm{BH}_{1}=-0.696 * * *$ & $\mathrm{BH}_{2}=-0.376^{*} * *$ & $\mathrm{TH}=-0.320 * * *$ \\
$(0.083)$ & $(0.006)$ & $(0.084)$ \\
\hline
\end{tabular}

(a) and (b) represent observed skewness (downside risk exposure), that is the third central moment $f_{3}\left(\mathbf{x}, \boldsymbol{\beta}_{3}\right)$ of production function (2); (c) and (d) represent the counterfactual expected downside risk exposure. (a) $E\left(y_{1 i} \mid A_{i}=1\right)$; (b) $E\left(y_{2 i} \mid A_{i}=0\right)$; (c) $E\left(y_{2 i} \mid A_{i}=1\right)$; (d) $E\left(y_{1 i} \mid A_{i}=0\right)$ where

$A_{i}=1$ if farm households adapted to climate change; $A_{i}=0$ if farm households did not adapt; $y_{I i}$ : third central moment if farm households adapted; $y_{2 i}$ : third central moment if farm households did not adapt; TT: the effect of the treatment (i.e., adaptation) on the treated (i.e., farm households that adapted); TU: the effect of the treatment (i.e., adaptation) on the untreated (i.e., farm households that did not adapt); $\mathrm{BH}_{\mathrm{i}}$ : the effect of base heterogeneity for farm households that adapted $(\mathrm{i}=1)$, and did not adapt $(\mathrm{i}=2)$; $\mathrm{TH}=(\mathrm{TT}-\mathrm{TU})$, i.e., transitional heterogeneity

Standard errors in parentheses. ***Significant at the $1 \%$ level

\section{Conclusions}

This paper investigated the implications of farm households' past decision to adapt to climate change on current downside risk exposure. We used a moment-based approach that captures the third moment of a stochastic production function as a measure of downside yield uncertainty. Then, we estimated a simultaneous equations model with endogenous switching to account for unobservable factors that influence downside risk exposure and the decision to adapt.

The first step of the analysis highlighted that the risk associated with the environmental characteristics of the farm such as soil fertility and access to information are key determinants of adaptation. These findings are consistent with Di Falco et al. (2011) on climate change adaption and food productivity, and Koundouri et al. (2006) on irrigation technology adoption under production uncertainty. Koundouri et al. (2006) emphasize that farm households that are better informed may value less the option to wait, and so are more likely to adopt new technologies than other farmers. This implies that waiting for gathering more and better information might have a positive value, and the provision of information on climate change might reduce the quasi-option value associated with adaptation. In addition, in this study we find that also education and past climatic factors significantly affect the adaptation decision. In particular, rainfall in both rainy seasons displays an $U$-shape behaviour, being literate or having experienced a flood in the past has a positive effect on the likelihood to adapt. Development policies that aim to increase education level can have positive spillovers in terms of adaptation and technology adoption in general. 
We can draw four main conclusions from the results of this study on the effects of climate change adaptation on downside risk exposure. First, past climate change adaptation reduces current downside risk exposure. Farm households that implemented climate change adaptation strategies obtained benefits in terms of a decrease in the risk of crop failure. Second, adaptation would have been more beneficial to farm households that previously did not adapt if they adapted. This group would have had a larger reduction on downside risk exposure compared to the group of adapters. This leads us to the third finding, namely, there are some important sources of heterogeneity and differences between adapters and non-adapters that make the non-adapters less exposed to downside risk than the adapters irrespective to the issue of climate change. These differences represent sources of variation between the two groups that the estimation of an OLS model including a dummy variable for adapting or not to climate change cannot take into account. Last but not least, climate change adaptation is a successful risk management strategy that makes the adapters more resilient to climatic conditions. The non-adapters are significantly affected by the rainfall in both the short and long rainy seasons while the adapters are much less affected by climatic factors.

It should be stressed, however, that there are very important caveats to our findings. First, our results derive from cross-sectional and plot level analysis. This does not allow an analysis of the dynamic aspects of risk management decisions. This is an important limitation of our study. Panel data would be required to explore such issues. To our knowledge, there is no climate change survey where the same household has been interviewed in different point in time. Future research should therefore be allocated to the construction of such panel data. This will allow to adequately addressing the dynamic dimension of the problem. A second important limitation of our study is that we do not distinguish among different types of adaptation. Di Falco and Veronesi (2013) find that, in Ethiopia, adaptation based upon a portfolio of strategies is significantly more effective than the adoption of strategies in isolation. Arguably some strategies may be more successful than others in dealing with risk exposure (e.g., changing crop varieties, implementing water harvesting technologies). Future research should thus also distinguish how different strategies may affect risk exposure. 


\section{Appendix}

Table A1 Variables definition

\begin{tabular}{|c|c|}
\hline Variable name & Definition \\
\hline \multicolumn{2}{|l|}{ Dependent variables } \\
\hline Adaptation & $\begin{array}{l}\text { Dummy }=1 \text { if the farm household adapted to climate change, } 0 \\
\text { otherwise }\end{array}$ \\
\hline Skewness & $\begin{array}{l}\text { Downside risk exposure: third central moment } f_{3}\left(\mathbf{x}, \boldsymbol{\beta}_{3}\right) \text { of production } \\
\text { function }(2) / 10 \text { milliards }\end{array}$ \\
\hline \multicolumn{2}{|l|}{ Explanatory variables } \\
\hline \multicolumn{2}{|l|}{ Climatic factors } \\
\hline Average temperature & Average temperature $\left({ }^{\circ} \mathrm{C}\right) 1970-2000$ \\
\hline Belg rainfall & Rainfall rate in Belg, short rainy season (mm) 1970-2000 \\
\hline Meher rainfall & Rainfall rate in Meher, long rainy season (mm) 1970-2000 \\
\hline \multicolumn{2}{|l|}{ Crop varieties } \\
\hline Barley & Dummy = 1 if the farm household grows barley, 0 otherwise \\
\hline Maize & Dummy $=1$ if the farm household grows maize, 0 otherwise \\
\hline Teff & Dummy = 1 if the farm household grows teff, 0 otherwise \\
\hline Wheat & Dummy $=1$ if the farm household grows wheat, 0 otherwise \\
\hline \multicolumn{2}{|l|}{ Soil characteristics } \\
\hline High fertility & Dummy $=1$ if the soil has a high level of fertility, 0 otherwise \\
\hline Infertile & Dummy $=1$ if the soil is infertile, 0 otherwise \\
\hline No erosion & Dummy = 1 if the soil has no erosion, 0 otherwise \\
\hline Severe erosion & Dummy = 1 if the soil has severe erosion, 0 otherwise \\
\hline \multicolumn{2}{|l|}{ Assets } \\
\hline Machinery & Dummy $=1$ if machineries are used, 0 otherwise \\
\hline Animals & Dummy = 1 if farm animal power is used, 0 otherwise \\
\hline \multicolumn{2}{|l|}{ Inputs } \\
\hline Labor & Labor use per hectare (adult days) \\
\hline Seeds & Seeds use per hectare $(\mathrm{kg})$ \\
\hline Fertilizers & Fertilizer use per hectare $(\mathrm{kg})$ \\
\hline Manure & Manure use per hectare $(\mathrm{kg})$ \\
\hline \multicolumn{2}{|c|}{ Farm head and farm household characteristics } \\
\hline Literacy & Dummy $=1$ if the household head is literate, 0 otherwise \\
\hline Male & Dummy $=1$ if the household head is male, 0 otherwise \\
\hline Married & Dummy $=1$ if the household head is married, 0 otherwise \\
\hline Age & Age of the household head \\
\hline Household size & Household size \\
\hline Off-farm job & Dummy $=1$ if the household head took an off-farm job, 0 otherwise \\
\hline
\end{tabular}


Table A1 (continued)

\begin{tabular}{|c|c|}
\hline Variable name & Definition \\
\hline Relatives & Number of relatives in the woreda \\
\hline Access to credit & $\begin{array}{l}\text { Dummy }=1 \text { if the farm household has access to formal credit, } 0 \\
\text { otherwise }\end{array}$ \\
\hline Flood & $\begin{array}{l}\text { Dummy }=1 \text { if the farm household experienced a flood during the last } \\
5 \text { years }\end{array}$ \\
\hline Drought & $\begin{array}{l}\text { Dummy }=1 \text { if the farm household experienced a drought during the } \\
\text { last } 5 \text { years }\end{array}$ \\
\hline \multicolumn{2}{|l|}{ Information sources } \\
\hline Government extension & $\begin{array}{l}\text { Dummy }=1 \text { if the household head received information/advice from } \\
\text { government extension workers, } 0 \text { otherwise }\end{array}$ \\
\hline $\begin{array}{l}\text { Farmer-to-farmer } \\
\text { extension }\end{array}$ & $\begin{array}{l}\text { Dummy }=1 \text { if the household head received information/advice from } \\
\text { farmer-to-farmer extension, } 0 \text { otherwise }\end{array}$ \\
\hline Radio information & $\begin{array}{l}\text { Dummy }=1 \text { if the household head received information from the } \\
\text { radio, } 0 \text { otherwise }\end{array}$ \\
\hline $\begin{array}{l}\text { Neighborhood } \\
\text { information }\end{array}$ & $\begin{array}{l}\text { Dummy }=1 \text { if the household head received information from the } \\
\text { neighborhood, } 0 \text { otherwise }\end{array}$ \\
\hline Climate information & $\begin{array}{l}\text { Dummy }=1 \text { if extension officers provided information on expected } \\
\text { rainfall and temperature, } 0 \text { otherwise }\end{array}$ \\
\hline
\end{tabular}

Table A2 Parameter estimates - Test on the validity of the selection instruments

\begin{tabular}{|c|c|c|}
\hline & Model 1 & Model 2 \\
\hline & Adaptation $1 / 0$ & Skewness non-adapters \\
\hline \multicolumn{3}{|l|}{ Information sources } \\
\hline \multirow[t]{2}{*}{ Government extension } & $0.526^{* * *}$ & -0.044 \\
\hline & $(0.112)$ & $(0.072)$ \\
\hline \multirow[t]{2}{*}{ Farmer-to-farmer extension } & $0.492^{* * *}$ & 0.050 \\
\hline & $(0.143)$ & $(0.085)$ \\
\hline \multirow[t]{2}{*}{ Radio information } & $0.464^{* * * *}$ & -0.050 \\
\hline & $(0.173)$ & $(0.043)$ \\
\hline \multirow[t]{2}{*}{ Neighborhood information } & 0.002 & $-0.070^{*}$ \\
\hline & $(0.178)$ & $(0.032)$ \\
\hline \multirow[t]{2}{*}{ Climate information } & $0.488^{* *}$ & 0.147 \\
\hline & $(0.201)$ & $(0.103)$ \\
\hline \multirow[t]{2}{*}{ Constant } & $-1.173^{* * *}$ & 0.056 \\
\hline & $(0.398)$ & $(0.055)$ \\
\hline Wald test on information sources & $\chi^{2}=108.27 * * *$ & F-stat. $=2.10$ \\
\hline Sample size & 2801 & 868 \\
\hline
\end{tabular}

Model 1: Probit model (Pseudo $\mathrm{R}^{2}=0.323$ ); Model 2: ordinary least squares $\left(\mathrm{R}^{2}=0.070\right)$. Other covariates include climatic factors, crop varieties, soil characteristics, assets, inputs, farm head and farm household characteristics as specified in Eqs. (1), (4a) and (4b). Estimation at the plot-level. Standard errors clustered at the woreda level in parentheses

*Significant at the $10 \%$ level; **Significant at the 5\% level; ***Significant at the $1 \%$ level 
Table A3 Parameters estimates of production function (2)

\begin{tabular}{|c|c|c|}
\hline $\begin{array}{l}\text { Dependent variable } \\
\text { Quantity produced per hectare }\end{array}$ & Adapters & Non-adapters \\
\hline \multicolumn{3}{|l|}{ Climatic factors } \\
\hline \multirow[t]{2}{*}{ Average temperature } & -202.129 & 268.006 \\
\hline & $(300.619)$ & $(291.700)$ \\
\hline \multirow[t]{2}{*}{ Squared average temperature } & 4.868 & -7.600 \\
\hline & $(7.573)$ & $(7.231)$ \\
\hline \multirow[t]{2}{*}{ Belg rainfall } & $4.952 *$ & 0.686 \\
\hline & $(2.433)$ & $(1.278)$ \\
\hline \multirow[t]{2}{*}{ Squared Belg rainfall/1000 } & $-8.367 * *$ & -3.602 \\
\hline & $(3.514)$ & $(2.131)$ \\
\hline \multirow{2}{*}{ Meher rainfall } & 1.070 & $1.744 * *$ \\
\hline & $(1.062)$ & $(0.678)$ \\
\hline \multirow{2}{*}{ Squared Meher rainfall/1000 } & -6.665 & $-7.935^{* *}$ \\
\hline & $(6.016)$ & $(3.369)$ \\
\hline \multicolumn{3}{|l|}{ Crop varieties } \\
\hline \multirow[t]{2}{*}{ Barley } & $288.879 * *$ & 10.664 \\
\hline & (109.089) & $(60.176)$ \\
\hline \multirow[t]{2}{*}{ Maize } & $461.443 * *$ & $222.103 * *$ \\
\hline & $(171.111)$ & $(83.758)$ \\
\hline \multirow[t]{2}{*}{ Teff } & -22.076 & -47.638 \\
\hline & $(109.614)$ & $(66.694)$ \\
\hline \multirow[t]{2}{*}{ Wheat } & 98.186 & 53.065 \\
\hline & $(88.497)$ & $(54.796)$ \\
\hline \multicolumn{3}{|l|}{ Soil characteristics } \\
\hline \multirow[t]{2}{*}{ Highly fertile } & 126.428 & 37.858 \\
\hline & $(73.932)$ & $(63.311)$ \\
\hline \multirow[t]{2}{*}{ Infertile } & $-150.982 * * *$ & -40.251 \\
\hline & $(44.538)$ & $(64.474)$ \\
\hline \multirow[t]{2}{*}{ No erosion } & -21.523 & -12.402 \\
\hline & $(73.277)$ & $(33.784)$ \\
\hline \multirow[t]{2}{*}{ Severe erosion } & 52.975 & -46.906 \\
\hline & $(134.095)$ & $(87.457)$ \\
\hline \multicolumn{3}{|l|}{ Assets } \\
\hline \multirow[t]{2}{*}{ Machinery } & $-278.976^{*}$ & -37.570 \\
\hline & $(155.387)$ & $(92.297)$ \\
\hline \multirow[t]{2}{*}{ Animals } & $203.901 * *$ & $146.169 * *$ \\
\hline & $(94.438)$ & $(63.333)$ \\
\hline \multicolumn{3}{|l|}{ Inputs } \\
\hline \multirow[t]{2}{*}{ Labor } & $3.888 * * *$ & $3.739 * * *$ \\
\hline & $(1.129)$ & $(1.005)$ \\
\hline \multirow[t]{2}{*}{ Squared labor/100 } & $-0.139 * * *$ & $-0.327 * * *$ \\
\hline & $(0.072)$ & $(0.087)$ \\
\hline
\end{tabular}


Table A3 (continued)

\begin{tabular}{l|l|l}
\hline $\begin{array}{l}\text { Dependent variable } \\
\text { Quantity produced per hectare }\end{array}$ & Adapters & Non-adapters \\
\hline Seeds & $1.805^{* *}$ & 0.588 \\
\hline & $(0.843)$ & $(0.798)$ \\
\hline Squared seeds/100 & $0.064^{*}$ & 0.245 \\
\hline Fertilizers & $(0.036)$ & $(0.161)$ \\
\hline & $1.298^{* * *}$ & $1.088^{* *}$ \\
\hline Squared fertilizers/100 & $(0.330)$ & $(0.441)$ \\
\hline & $-0.020^{* * *}$ & $-0.026^{* *}$ \\
\hline Manure & $(0.006)$ & $(0.010)$ \\
\hline Squared manure/100 & $0.186^{* * *}$ & -0.021 \\
\hline & $(0.046)$ & $(0.136)$ \\
\hline Farm & $-0.002^{* *}$ & $0.004^{* *}$ \\
\hline & $(0.001)$ & $(0.002)$ \\
\hline
\end{tabular}

Farm head and farm household characteristics

\begin{tabular}{l|l|l}
\hline Literacy & -22.475 & $-118.383^{* *}$ \\
\hline Male & $(53.907)$ & $(51.700)$ \\
\hline & 224.332 & $334.423^{* * *}$ \\
\hline Married & $(166.045)$ & $(90.036)$ \\
\hline Age & -28.748 & -224.175 \\
\hline & $(126.850)$ & $(143.732)$ \\
\hline Household size & -3.076 & $-3.323 *$ \\
\hline Off-farm job & $(2.157)$ & $(1.763)$ \\
\hline & 4.958 & 7.465 \\
\hline Relatives & $(15.826)$ & $(10.927)$ \\
\hline Access to credit & $168.830^{*}$ & -8.177 \\
\hline & $(85.889)$ & $(62.114)$ \\
\hline Flood & 0.162 & -1.087 \\
\hline & $(0.185)$ & $(2.020)$ \\
\hline Drought & -50.871 & $-264.125^{* * *}$ \\
\hline & $(88.492)$ & $(47.731)$ \\
\hline Mundlak's fixed effects & -64.011 & -107.933 \\
\hline Mean fertilizers & $(80.790)$ & $(114.596)$ \\
\hline & -102.393 & 61.738 \\
\hline Mean seeds & $(82.838)$ & $(189.641)$ \\
\hline Mean manure & & \\
\hline & $-0.534^{*}$ & -0.103 \\
\hline & $(0.262)$ & $(0.388)$ \\
\hline & 0.915 & 0.423 \\
\hline & $(0.654)$ & $(0.416)$ \\
\hline & -0.021 & -0.015 \\
\hline & $(0.054)$ & $(0.172)$ \\
\hline & $-1.419 * *$ & -0.992 \\
\hline & & \\
\hline & & \\
\hline & & \\
\hline
\end{tabular}


Table A3 (continued)

\begin{tabular}{l|l|l}
\hline $\begin{array}{l}\text { Dependent variable } \\
\text { Quantity produced per hectare }\end{array}$ & Adapters & Non-adapters \\
\hline & $(0.606)$ & $(0.581)$ \\
\hline Constant & 1269.038 & -2547.265 \\
\hline & $(3097.326)$ & $(2894.935)$ \\
\hline Sample size & 1933 & 868 \\
\hline Adj. $\mathbf{R}^{2}$ & 0.304 & 0.328 \\
\hline
\end{tabular}

Estimation by Ordinary Least Squares at the plot-level. Sample size: 2801 plots. Robust standard errors clustered at the woreda level in parentheses

*Significant at the $10 \%$ level; **Significant at the $5 \%$ level; ***Significant at the $1 \%$ level

\section{References}

Antle JM (1983) Testing the stochastic structure of production: A flexible moment-based approach. J Business and Economic Statistics 1:192-201

Antle JM, Goodger WM (1984) Measuring stochastic technology: the case of tulare milk production American J Agricultural Economics 66:342-350

Bandiera O, Rasul I (2006) Social networks and technology adoption in northern Mozambique. Economic J 116(514):869-902

Carter DW, Milon JW (2005) Price knowledge in household demand for utility services. Land Economics 81(2):265-283

Chavas J-P (2004) Risk analysis in theory and practice. Elsevier London

Cline WR (2007) Global warming and agriculture impact estimates by country. Washington DC: Center for Global Development and Peter G Peterson Institute For International Economics

Conley T, Udry C (2010) Learning about a new technology: Pineapple in Ghana. American Economic Review 100(1):35-69

Daly C (2006) Guidelines for assessing the suitability of spatial climate datasets. International J Climatology 26:707-721

Dercon S (2004) Growth and shocks: evidence from rural Ethiopia. J Development Economics 74(2):309-329

Dercon S (2005) Risk, poverty and vulnerability in Africa. J African Economies 14(4):483-488

Deressa TT, Hassan RM, Ringler C, Alemu T, Yesuf M (2009) Determinants of farmers' choice of adaptation methods to climate change in the Nile Basin of Ethiopia. Global Environmental Change 19(2):248-255

Deressa TT, Hassan RH (2009) Economic impact of climate change on crop production in Ethiopia: Evidence from cross-section measures. J African Economies 18(4):529-554

Deressa TT, Hassan RM, Ringler C (2011) Perception of and adaptation to climate change by farmers in the Nile Basin of Ethiopia. J Agricultural Science 149(1):23-31

Di Falco S, Chavas J-P (2009) On crop biodiversity, risk exposure and food security in the Highlands of Ethiopia. American J Agricultural Economics 91(3):599-611

Di Falco S, Veronesi M, Yesuf M (2011) Does adaptation to climate change provide food security? A micro-perspective from Ethiopia. American J Agricultural Economics 93(3):829-846

Di Falco S, Veronesi M (2013). How African agriculture can adapt to climate change? A counterfactual analysis from Ethiopia. Land Economics 
Dinar A, Hassan R, Mendelsohn R, Benhin J et al (2008) Climate change and agriculture in Africa: Impact assessment and adaptation strategies. London: EarthScan

Gadisso BE (2007) Drought assessment for the Nile Basin using Meteosat second generation data with special emphasis on the upper Blue Nile Region. PhD Thesis International Institute for Geo-Information Science and Earth Observation. Eschede: The Netherlands

Gbetibouo G, Hassan R (2005) Economic impact of climate change on major South African field crops: A Ricardian approach. Global and Planetary Change 47:143-152

Gbetibouo G, Hassan R, Ringler C (2010) Modelling farmers' adaptations strategies to climate change and variability: The case of the Limpopo Basin, South Africa. Agrekon 49(2):217-234

Hagos F, Pender J, Gebreselassie N (1999) Land degradation in the highlands of Tigray and strategies for sustainable land management. (First edition) Socio-economics and Policy Research Working Paper 25 ILRI (International Livestock Research Institute). Addis Ababa Ethiopia $80 \mathrm{pp}$

Hartman RS (1991) A Monte Carlo analysis of alternative estimators in models involving selectivity. J Business and Economic Statistics 9:41-49

Hassan R, Nhemachena C (2008) Determinants of African farmers' strategies for adaptation to climate change: Multinomial choice analysis. African J Agricultural and Resource Economics 2(1):83-104

Heckman JJ, Tobias JL, Vytlacil EJ (2001) Four parameters of interest in the evaluation of social programs. Southern Economic J 68(2): 210-233

International Food Policy Research Institute (IFPRI) (2010) Ethiopia Nile Basin climate change adaptation dataset. Food and water security under global change: Developing adaptive capacity with a focus on rural Africa, Washington DC

Just RE, Pope RD (1979) Production function estimation and related risk considerations. American J Agricultural Economics 61:276-284

Kim K, Chavas J-P (2003) Technological change and risk management: An application to the economics of corn production. Agricultural Economics 29:125-142

Koundouri P, Nauges C, Tzouvelekas V (2006) Technology adoption under production uncertainty: Theory and application to irrigation technology. American J Agricultural Economics 88(3):657-670

Kurukulasuriya P, Mendelsohn R (2008) Crop switching as an adaptation strategy to climate change. African J Agriculture and Resource Economics 2:105-125

Kurukulasuriya P, Kala N, Mendelsohn R (2011) Adaptation and climate change impacts: A structural Ricardian model of irrigation and farm income in Africa. Climate Change Economics 2(2):149-174

Lautze S, Aklilu Y, Raven-Roberts A, Young H, Kebede G, Learning J (2003) Risk and vulnerability in Ethiopia: Learning from the past, responding to the present, preparing for the future. Report for the US Agency for International Development Addis Ababa, Ethiopia

Lee LF, Trost RP (1978) Estimation of some limited dependent variable models with application to housing demand. J Econometrics 8:357-382

Lobell DB, Burke MB, Tebaldi C, Mastrandrea MM, Falcon WP, Naylor RL (2008) Prioritizing climate change adaptation needs for food security in 2030. Science 319:607-610

Lokshin M, Sajaia Z (2004) Maximum likelihood estimation of endogenous switching regression models. Stata J 4(3):282-289

Maddala GS (1983) Limited dependent and qualitative variables in econometrics. Cambridge, UK: Cambridge University Press

Maddala GS, Nelson FD (1975) Switching regression models with exogenous and endogenous switching. Proceeding of the American Statistical Association (Business and Economics Section) $423-426$ 
Maddison D (2006) The perception of and adaptation to climate change in Africa. CEEPA Discussion Paper No 10 Centre for Environmental Economics and Policy in Africa Pretoria, South Africa: University of Pretoria

Mendelsohn R (2000) Efficient adaptation to climate change. Climatic Change 45:583-600

Mendelsohn R, Dinar A (2003) Climate, water, and agriculture. Land Economics 79:328-341

Mendelsohn R, Nordhaus W, Shaw D (1994) The impact of global warming on agriculture: A Ricardian analysis. American Economic Review 84(4):753-771

Menezes C, Geiss C, Tressler J (1980) Increasing downside risk. American Economic Review 70:921-932

MoFED (Ministry of Finance and Economic Development) (2007) Ethiopia: Building on progress: A plan for accelerated and sustained development to end poverty (PASDEP). Annual Progress Report: Addis Ababa, Ethiopia

Mundlak Y (1978) On the pooling of time series and cross section data. Econometrica 46(1):69-85

Nawata K (1994) Estimation of sample selection bias models by the maximum likelihood estimator and Heckman's two-step estimator. Economics Letters 45:33-40

Nelson FD (1984) Efficiency of the two-step estimator for models with endogenous sample selection. J Econometrics 24:181-196

Orindi V, Ochieng A, Otiende B, Bhadwal S, Anantram K, Nair S, Kumar V, Kelkar U (2006) Mapping climate vulnerability and poverty in Africa. In PK Thornton, PG Jones, T Owiyo, RL Kruska, M Herrero, P Kristjanson, A Notenbaert, N Bekele, A Omolo Mapping climate vulnerability and poverty in Africa. Report to the Department for International Development. International Livestock Research Institute (ILRI), Nairobi

Parry M, Rosenzweig C, Livermore M (2005) Climate change, global food supply and risk of hunger. Phil Trans Royal Soc B 360:2125-2138

Relief Society of Tigray (REST) and NORAGRIC at the Agricultural University of Norway (1995) Farming systems, resource management and household coping strategies in Northern Ethiopia: Report of a social and agro-ecological baseline study in central Tigray Aas. Norway

Rosenzweig C, Parry ML (1994) Potential impact of climate change on world food supply. Nature 367:133-138

Schlenker W, Lobell DB (2010) Robust negative impacts of climate change on African agriculture. Environmental Research Letters 5:1-8

Seo SN, Mendelsohn R (2008a) An analysis of crop choice: Adapting to climate change in Latin American farms. Ecological Economics 67:109-116

Seo SN, Mendelsohn R (2008b) Measuring impacts and adaptations to climate change: A structural Ricardian model of African livestock management. Agricultural Economics 38(2):151-165

Seo N, Mendelsohn R, Dinar A, Hassan R, Kurukulasuriya P (2009) A ricardian analysis of the distribution of climate change impacts on agriculture across agro-ecological zones in Africa. Environmental and Resource Economics 43(3):313-332

Stige LC, Stave J, Chan K, Ciannelli L, Pattorelli N, Glantz M, Herren H, Stenseth N (2006) The effect of climate variation on agro-pastoral production in Africa. PNAS 103:3049-3053

Udry C (1996) Gender, agricultural production, and the theory of the household. J Political Economy 104(5):1010-1046

Wahba G (1990) Spline models for observational data. Philadelphia: Society for Industrial and Applied Mathematics

Wooldridge JM (2002) Econometric analysis of cross section and panel data. Cambridge, MA: MIT Press 
World Bank (2006) Ethiopia: Managing water resources to maximize sustainable growth. A World Bank Water Resources Assistance Strategy for Ethiopia. BNPP Report TF050714. Washington DC

World Bank (2010) World development report. Development and climate change. The International Bank for Reconstruction and Development/The World Bank 1818 H Street NW Washington DC 20433

Open Access This chapter is distributed under the terms of the Creative Commons AttributionNonCommercial-ShareAlike 3.0 IGO license (https://creativecommons.org/licenses/by-nc-sa/3.0/ $\mathrm{igo} /$ ), which permits any noncommercial use, duplication, adaptation, distribution, and reproduction in any medium or format, as long as you give appropriate credit to the Food and Agriculture Organization of the United Nations (FAO), provide a link to the Creative Commons license and indicate if changes were made. If you remix, transform, or build upon this book or a part thereof, you must distribute your contributions under the same license as the original. Any dispute related to the use of the works of the FAO that cannot be settled amicably shall be submitted to arbitration pursuant to the UNCITRAL rules. The use of the FAO's name for any purpose other than for attribution, and the use of the FAO's logo, shall be subject to a separate written license agreement between the FAO and the user and is not authorized as part of this CC-IGO license. Note that the link provided above includes additional terms and conditions of the license.

The images or other third party material in this chapter are included in the chapter's Creative Commons license, unless indicated otherwise in a credit line to the material. If material is not included in the chapter's Creative Commons license and your intended use is not permitted by statutory regulation or exceeds the permitted use, you will need to obtain permission directly from the copyright holder.$$
\text { (C) } \mathcal{( 1 )} \Theta
$$ 